\section{International Scientific Journal Theoretical \& Applied Science}

\author{
p-ISSN: 2308-4944 (print) e-ISSN: 2409-0085 (online) \\ Year: $2016 \quad$ Issue: 6 Volume: 38 \\ Published: $30.06 .2016 \quad \underline{\text { http://T-Science.org }}$
}

SECTION 9. Chemistry and chemical technology.
Sabir Ahmad Mammadov

Doctor in Chemistry, Professor, Head of Laboratory, Institute of Chemistry of Additives,

Azerbaijan National Academy of Sciences, Azerbaijan sabir.mamedov.39@mail.ru

Nina Petrovna Ladokhina

PhD in Chemistry, Assistant professor, Leadinq Scientific Researcher, Institute of Chemistry of Additives, Azerbaijan National Academy of Sciences, Azerbaijan nina62_62@mail.ru

Leyla Mais Shakhgel'dieva $\mathrm{PhD}$ in Chemistry, Senior Scientific Researcher, Institute of Chemistry of Additives,

Azerbaijan National Academy of Sciences, Azerbaijan leylashahgeldiyeva@yahoo.com

Sevgili Ismayil Mammadova

$\mathrm{PhD}$ in Chemistry, doctorant, Institute of Chemistry of Additives, Azerbaijan National Academy of Sciences, Azerbaijan alximikseva@rambler.ru

Lamiya Ismayil Aliyeva aspirant, Institute of Chemistry of Additives, Azerbaijan National Academy of Sciences, Azerbaijan

\title{
SYNTHESIS OF CONJUGATED SULFONAMIDES AND THEIR HETEROCYCLIC DERIVATIVES
}

\footnotetext{
Abstract: Ethoxymethylene malonodinitrile was found to be an active reagent in the synthesis of N-2,2dicyanoethylene sulfonamides. In the obtained compounds, the nitrile groups had different spatial arrangements, and, therefore, upon their interaction with hydrogen sulfide, even in the cold, only one nitrile group transformed into the thioacetamide group. The interaction between the sulfonamides and hydrazine and hydroxylamine produced pyrazoline- and oxazoline derivatives of sulfonamides. Upon reaction with arylsulfonyl guanidine, ethoxymethylene malonodinitrile easily underwent heterocyclization with a high yield of $N$-3-amino-4-Z-Rarylsulfonyl pyrimidines.

Key words: hetaryl sulfonamides, ethoxymethylene malonodinitrile, pyrimidine-, oxazoline- and pyrazoline sulfonamides, alkylating agent.

Language: English

Citation: Mammadov SA, Ladokhina NP, Shakhgel'dieva LM, Mammadova SI, Aliyeva LI (2016) SYNTHESIS OF CONJUGATED SULFONAMIDES AND THEIR HETEROCYCLIC DERIVATIVES. ISJ Theoretical \& Applied Science, 06 (38): 1-5.

Soi: http://s-o-i.org/1.1/TAS-06-38-1 Doi: crossef http://dx.doi.org/10.15863/TAS.2016.06.38.1
}

\section{INTRODUCTION}

The presence of heterocyclic units in sulfonamides broadens their spectrum of activity against pathogenic microorganisms. The emergence of drug-resistant strains of microorganisms necessitates the development of novel sulfonamide compounds with specific antimicrobial properties.

The synthesis of hetaryl sulfonamides involves their activation with functionally substituted fragments. For instance, the synthesis of sulfonamides containing a thiazolidine group involves the production of an active form of the compound through the reaction of arylsulfanyl hydrazine with aldehydes [1, P.627]. It was found that nucleophilic 5-endo-trig cyclization of $\mathrm{N}$ homoallyl sulfonamides is a simple way of construction of pyrrolidine cycles [2, P.2693).

A reaction between sulfonamides with an acyl group and aromatic aldehydes was used to obtain 
chalcones which appeared to be active synthons for heterocyclic compounds [3, P.475]. Upon reaction with malononitrile, hydrazine, hydroxylamine and urea in the presence of $\mathrm{AcONH}_{4}$, they produce, respectively, pyridine, pyrazole, isoxazole and piperidine derivatives. Reactions between arensulfonyl imines and N,N-dinucleophiles result in the production of various $\mathrm{N}$-sulfonylized heterocycles [4, P.2171].

2-Phenyl quinoxaline was synthesized by using as synthons1-functionally substituted N-(2-phenyl2,2-dichlorethyl)arensulfonamides which form heterocycles with ortho-phenylenediamine $[5$, P.470].

The synthesis of synthons for construction of various heterocyclic compounds was extensively described in [6]. There is a vast amount of information on synthesis of bipolar synthons and their heterocyclization available elsewhere.

Ethoxymethylene malonodinitrile (EMMD) is a promising agent for production of bipolar conjugated sulfonamides. Even though EMMD and its properties were investigated in the past [7, P.4889], its use as an alkylating agent was described relatively recently [8, P.92].

\section{EXPERIMENTAL}

Infrared spectra of the synthesized compounds were obtained on Nicolet iS10 spectrophotometer.

NMR spectra were recorded on Varian T-60, Tesla-477 and Bruker-250 operating at 60, 80 and $250 \mathrm{mHz}$ frequency, respectively.

Synthesis of N-(2,2-Dicyanoethynyl)aryl sulfonamides I(a-d).

General procedure: 0.05 moles of arylsulfonamide $\mathrm{I}(\mathrm{a}-\mathrm{c})$ were dissolved in $50 \mathrm{ml}$ of absolute ethanol; 0.06 moles of $\mathrm{NaOH}$ or $\mathrm{KOH}$ were added; the mixture was boiled for $30 \mathrm{~min}$ and then cooled, after which 0.05 moles of ethoxymethylene malonodinitrile were added. The mixture was boiled for 1.5-2 hours and then evaporated until its amount was reduced by half. After cooling and filtration of the sediment, the solution was recrystallized from a mixture of benzene and ethanol.

Compound I(a). Upon recrystallization from benzene, the yield was $11.8 \mathrm{~g}(87.3 \%)$. Melting point: $280{ }^{\circ} \mathrm{C} \mathrm{dec}$.

Compound I(b). Yield: $11.3 \mathrm{~g}(83.8 \%)$. Melting point: $268{ }^{0} \mathrm{C}$ dec. Found, \%: N, 15.47. $\mathrm{C}_{11} \mathrm{H}_{8} \mathrm{~N}_{3} \mathrm{O}_{2} \mathrm{SNa}$. Calculated, \%: N 15.81.

Compound I(c). Yield: $79.9 \%$. Melting point: $268{ }^{0} \mathrm{C}$ dec. (from benzene). Found, \%: C 59.72; $\mathrm{H}$ 4.26; N 12.19. $\mathrm{C}_{8} \mathrm{H}_{15} \mathrm{~N}_{3} \mathrm{O}_{2} \mathrm{~S}$. Calculated, \%: C 61.15, H 4.43, N 11.93.

Compound I(d) was obtained by the abovedescribed procedure with the only difference that the target product was precipitated during the boiling. It was then filtered, flushed out with water, dried, and recrystallized from ethanol. Yield: $87.6 \%$. Melting point: $151-152{ }^{0} \mathrm{C}$. Found, \%: C 59.6, H 3.09, N 12.16. $\mathrm{C}_{16} \mathrm{H}_{11} \mathrm{~N}_{3} \mathrm{O}_{2} \mathrm{~S}$. Calculated, \%: C 59.07, H 3.41, $\mathrm{N}$ 12.92.The infrared spectrum did not contain any absorption bands for $\mathrm{NH}$ and $\mathrm{OH}$ groups, which means that the obtained compound is a cyclic product. The difference in the absorption bands of the two nitrile groups (2210 и $\left.2220 \mathrm{~cm}^{-1}\right)$ is an indication of their different spatial arrangements.

Synthesis of N-2-Methoxyphenyl-N-2,2cyanothioacetamide methylene-4-methyl phenyl sulfonamide (IIa) and -1-phenylsulfonyl-2(cyanothiocarbamoyl)methyl-1,3-benzoxazole (IIb).

Dry hydrogen sulfate was bubbled through the solution of $50 \mathrm{~g}$ of compound $\mathrm{I}(\mathrm{c})$ or $\mathrm{I}(\mathrm{d})$ in ethyl alcohol until a complete fall-out of the yellow precipitate. The mixture was heated at $50-60{ }^{0} \mathrm{C}$ for $15 \mathrm{~min}$ and then cooled. The precipitate was filtered and recrystallized from ethanol.

Compound II(a). Yield: $81.6 \%$. Melting point: 204-206 ${ }^{\circ}$ C. Found, \%: C 53.28, H 4.01, N 11.81, S 18.12. $\mathrm{C}_{18} \mathrm{H}_{17} \mathrm{~N}_{3} \mathrm{O}_{3} \mathrm{~S}_{2}$. Calculated, \%: C 53.47, $\mathrm{H}$ 3.65, N 11.69, S 17.84.

Compound II(a). Yield: $81.6 \%$. Melting point: 204-206 ${ }^{\circ} \mathrm{C}$. Found, \%: C 53.28, H 4.01, N 11.81, S 18.12. $\mathrm{C}_{18} \mathrm{H}_{17} \mathrm{~N}_{3} \mathrm{O}_{3} \mathrm{~S}_{2}$. Calculated, \%: C 53.47, $\mathrm{H}$ 3.65, N 11.69, S 17.84.

Compound II(b). Yield: $85.8 \%$. Melting point: 196-198 ${ }^{\circ}$ C. Found, \%: C 56.22, H 4.73, N 11.41, S 16.23. $\mathrm{C}_{16} \mathrm{H}_{13} \mathrm{~N}_{3} \mathrm{O}_{3} \mathrm{~S}$. Calculated, \%: C 55.80, H 4.42, $\mathrm{N} 10.84$, S 16.55. NMR spectrum ${ }^{1} \mathrm{H}, \mathrm{CDCl}_{3}, \delta$. ppm: $2.15 \mathrm{~s}\left(\mathrm{NH}_{2}\right), 7.95 \mathrm{~m}(2 \mathrm{H}, \mathrm{CH}-\mathrm{CH}), 7.22-7.65$ $\left(5 \mathrm{H}, \mathrm{C}_{6} \mathrm{H}_{5}\right), 7.65-7.8\left(4 \mathrm{H}, \mathrm{C}_{6} \mathrm{H}_{4}\right)$.

Synthesis of 4-Amino-2-aryl sulfamide-5cyano pyrimidines (IIIa-b).

0.01 moles of aryl sulfonyl guanidine were dissolved in $30 \mathrm{ml}$ of absolute ethanol. $1 \mathrm{ml}$ of morpholine and 0.01 moles of ethoxymethylene malonodinitrile were added to the solution. The mixture was boiled for 30-35 min, cooled, and neutralized by adding ice-cold acetic acid. The precipitated crystals were collected by filtration, flushed with water and recrystallized from ethanol

Compound III(a). Yield: $74.9 \%$. Melting point: $208-210{ }^{0} \mathrm{C}$. Found, \%: C 49.59, H 4.11, N 24.05, S 11.65. $\mathrm{C}_{11} \mathrm{H}_{8} \mathrm{~N}_{3} \mathrm{O}_{2} \mathrm{~S}$. Calculated, \%: C 49.77, $\mathrm{H}$ 3.83, N 24.29, S 11.07. NMR spectrum ${ }^{1} \mathrm{H}$, DMSO, $\delta$. ppm: $6.1 \mathrm{~s}(\mathrm{NH}), 8.3 \mathrm{~m}\left(\mathrm{NH}_{2}\right), 7.1-7.8$ $\left(\mathrm{SH}, \mathrm{C}_{6} \mathrm{H}_{5}\right.$ ).

Compound III(b). Yield: $70.1 \%$. Melting point: $188-190{ }^{\circ} \mathrm{C}$. Found, \%: C 49.69, H 3.71, N 


\begin{tabular}{|c|c|c|c|c|c|c|}
\hline Impact Factor: & $\begin{array}{l}\text { ISRA (India) } \\
\text { ISI (Dubai, UAF } \\
\text { GIF (Australia) } \\
\text { JIF }\end{array}$ & $\begin{array}{l}=1.344 \\
=0.829 \\
=0.564 \\
=1.500\end{array}$ & $\begin{array}{l}\text { SIS (USA) } \\
\text { PИНЦ (Russia) } \\
\text { ESJI (KZ) } \\
\text { SJIF (Morocco) }\end{array}$ & $\begin{array}{l}=0.912 \\
=0.234 \\
=1.042 \\
=2.031\end{array}$ & $\begin{array}{l}\text { ICV (Poland) } \\
\text { PIF (India) } \\
\text { IBI (India) }\end{array}$ & $\begin{array}{l}=6.630 \\
=1.940 \\
=4.260\end{array}$ \\
\hline
\end{tabular}

24.43. $\mathrm{C}_{12} \mathrm{H}_{11} \mathrm{~N}_{5} \mathrm{O}_{2} \mathrm{~S}$. Calculated, \%: C 49.82, $\mathrm{H}$ $3.83, \mathrm{~N} 24.21$.

Synthesis of 3-Amino-4-cyano-5-N(arylsulfonamide)-1,2-pyrazolines (IVa-b) and oxazoline (IVc).

25 mmoles of compound I(a) or I(b) and 30 mmoles of hydrazine hydrate and hydroxylamine were dissolved in $50 \mathrm{ml}$ of ethanol. $3 \mathrm{ml}$ of $5 \mathrm{~N}$ $\mathrm{NaOH}$ were added to the reaction mixture, which was then boiled for 40-50 min and cooled. The precipitated crystals were collected by filtration, flushed with water and recrystallized from ethanol.

Compound IV(a). Yield: $52.8 \%$. Melting point: $225-226{ }^{0} \mathrm{C}$. Found, \%: C 45.82, H 4.31, N 26.98. $\mathrm{C}_{10} \mathrm{H}_{10} \mathrm{~N}_{5} \mathrm{O}_{2} \mathrm{~S}$. Calculated, \%: $\mathrm{C} 45.49, \mathrm{H}$ $3.81, \mathrm{~N} 26.58$.
Compound IV(b). Yield: $67.8 \%$. Melting point: $272.5-273.5{ }^{\circ} \mathrm{C}$. Found, \%: C 47.69, H 4.81, N 24.04. $\mathrm{C}_{11} \mathrm{H}_{12} \mathrm{~N}_{5} \mathrm{O}_{2} \mathrm{~S}$. Calculated, \%: C 47.42, $\mathrm{H}$ 4.34, N 25.24.

Compound IV(c). Yield: $55.1 \%$. Melting point: $271.5-272.5{ }^{\circ} \mathrm{C}$. Found, \%: C 47.29, H 4.61, N 20.88. $\mathrm{C}_{11} \mathrm{H}_{11} \mathrm{~N}_{4} \mathrm{O}_{2} \mathrm{~S}$. Calculated, \%: C 47.09, H 4.31, N 20.06. NMR spectrum ${ }^{1} \mathrm{H}, \mathrm{CDCl}_{3}, \delta$. ppm: $2.315\left(3 \mathrm{H}, \mathrm{CH}_{3}\right), 3.4 \mathrm{~s}\left(2 \mathrm{H}, \mathrm{NH}_{2}\right), 6.7 \mathrm{~d}(\mathrm{NH}$ oxazoline), $7.55 \mathrm{~d}$ (2H arom.), $7.7 \mathrm{~d}\left(2 \mathrm{H}_{\mathrm{B}}\right.$, arom.).

\section{RESULTS AND DISCUSSION}

Our study shows that this compound appears to be an active $\mathrm{N}$-alkylation reagent for sulfonamide compounds under mild conditions:

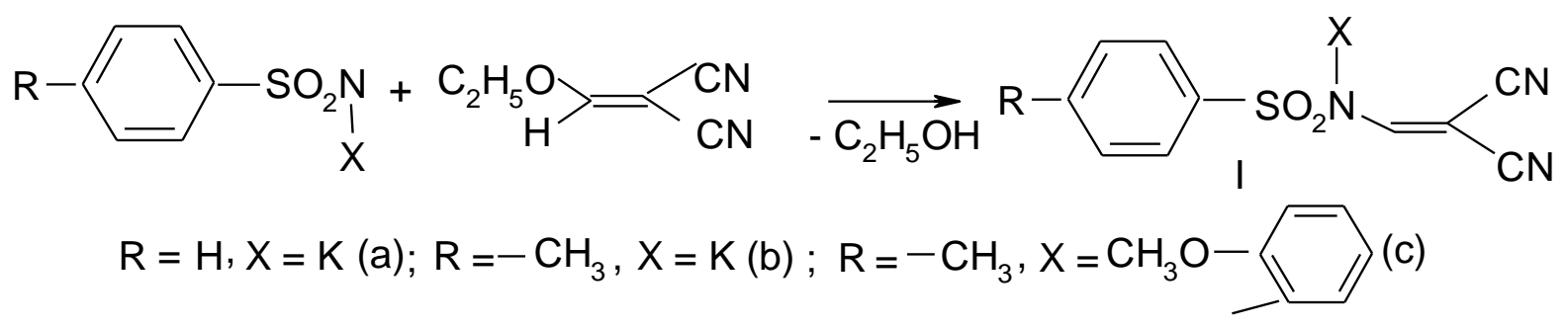

Scheme 1

The reaction between EMMD and benzenesulfo-N-(2-oxyfenyl)amide has some

peculiarities. First, there occurs a condensation reaction, which is then followed by cyclization:

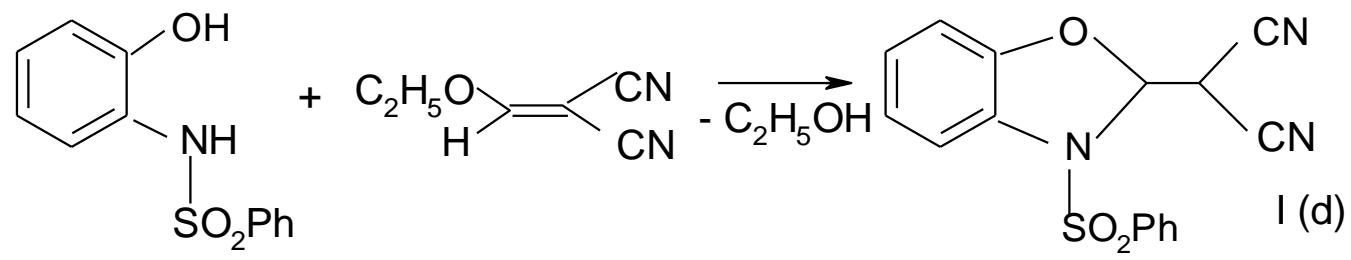

Scheme 2

The mass spectrum of compound I(d) shows that one of the main directions of disintegration of the molecular ion is due to characteristic breakdown of a malonodinitrile group as evidenced by the peak at $\mathrm{m} / \mathrm{z} 259$.

The infrared spectra of compounds I(a-d) show a difference in the absorption bands of two nitrile groups ( 2210 and $2220 \mathrm{~cm}^{-1}$ ), which proves that they have different spatial arrangements. This is apparently due to the influence of the sulfonamide group on the closest nitrile group. Therefore, upon the interaction of compounds $\mathrm{I}(\mathrm{c})$ and $\mathrm{I}(\mathrm{d})$ with hydrogen sulfate, even in the cold, only one nitrile group is transformed into the thioacetamide group: 


\begin{tabular}{l|lrl|l|ll} 
& ISRA (India) & $=\mathbf{1 . 3 4 4}$ & SIS (USA) & $=\mathbf{0 . 9 1 2}$ & ICV (Poland) & $=\mathbf{6 . 6 3 0}$ \\
Impact Factor: & ISI (Dubai, UAE) $=\mathbf{0 . 8 2 9}$ & PUHU (Russia) $=\mathbf{0 . 2 3 4}$ & PIF (India) & $=\mathbf{1 . 9 4 0}$ \\
& GIF (Australia) & $\mathbf{0 . 5 6 4}$ & ESJI (KZ) & $=\mathbf{1 . 0 4 2}$ & IBI (India) & $\mathbf{4 . 2 6 0}$
\end{tabular}

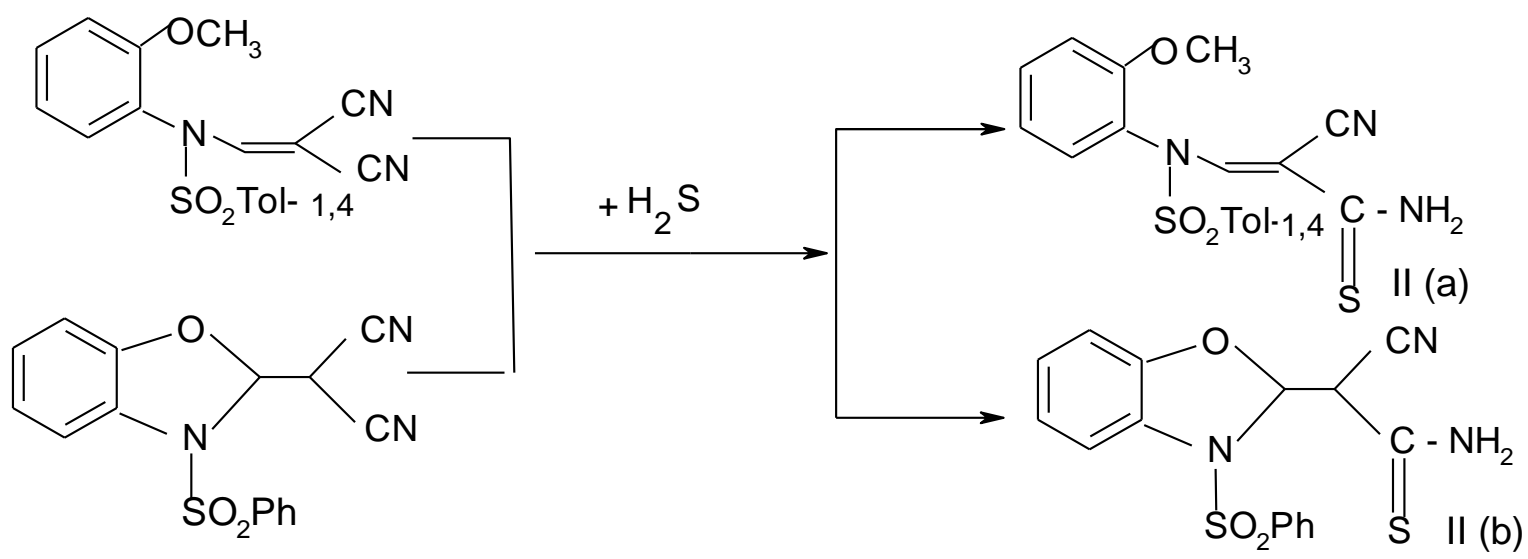

Scheme 3

EMMD and its derivatives easily bind with guanidine sulfonamides and form pyrimidine sulfonamides in $75-80 \%$ yield:<smiles>[R]c1ccc(S(=O)(=O)N(C=CC)C(=N)N)cc1</smiles>

\section{Scheme 4}

Pyrazolederivatives of sulfamides have a high antimicrobial activity [9, P.159]. They can be used as anti-inflammatory, as well as analgesic drugs [10, 11]. Pyrazole containing N-acylsulfonamides appeared to be strong EP-3 receptor antagonists (12). Their scope mainly depends on the composition of functional groups. Synthesis of such compounds is of interest.

$\mathrm{N}$-(2,2-Dicyanoethynyl)aryl sulfonamides I(a-b) appeared to be effective synthons in the synthesis of oxazoline- and pyrazoline sulfonamides in $55-60 \%$ yield:

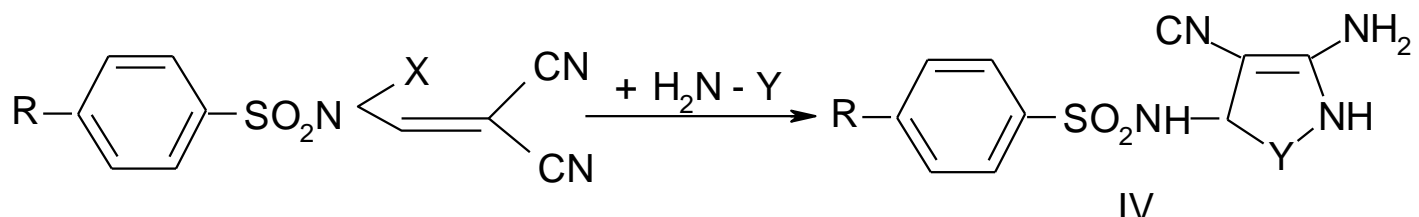

$$
\mathrm{R}=\mathrm{H}, \mathrm{Y}=-\mathrm{NH}(\mathrm{a}) ; \mathrm{R}=-\mathrm{CH}_{3}: \mathrm{Y}=-\mathrm{NH}(\mathrm{b}), \mathrm{Y}=\mathrm{O}(\mathrm{c}) ; \mathrm{X}=\mathrm{Na}, \mathrm{K}
$$

Scheme 5

The compound (IVb) was studied for antimicrobial activity. Results are given in the table 1.

Optimum concentration for suppression of Staphylococus aureus is found to be $1 \mathrm{~mol} / 1 \cdot \mathrm{min}$. $\cdot 10^{-2}$; Escherichia tuphi $-1,2 \mathrm{~mol} / 1 \cdot \min . \cdot 10^{-2}$; Penicillium $-2,9 \mathrm{~mol} / 1 \cdot \mathrm{min} \cdot \cdot 10^{-2}$.
The investigation showed that synthesized dinitrilesulfamides are synthons for the synthesis of biologically active heterocyclic compounds. These compounds, like 1,3-dipolar, synchronously attach to 1,2- and 1,3-polarophiles without the isolation of intermediates. Biological testing showed their high antimicrobial properties. 


\begin{tabular}{l|lrl|l|ll} 
& ISRA (India) & $=\mathbf{1 . 3 4 4}$ & SIS (USA) & $=\mathbf{0 . 9 1 2}$ & ICV (Poland) & $=\mathbf{6 . 6 3 0}$ \\
Impact Factor: & ISI (Dubai, UAE) $=\mathbf{0 . 8 2 9}$ & PUHU (Russia) $=\mathbf{0 . 2 3 4}$ & PIF (India) & $=\mathbf{1 . 9 4 0}$ \\
& GIF (Australia) & $\mathbf{0 . 5 6 4}$ & ESJI (KZ) & $=\mathbf{1 . 0 4 2}$ & IBI (India) & $\mathbf{4 . 2 6 0}$
\end{tabular}

Bactericidal properties of 3-amino-4-cyano-5-(4-methylphenylsulfamido)-1,2-pyrazoline.

Table 1.

\begin{tabular}{|c|c|c|c|c|}
\hline \multirow{2}{*}{$\begin{array}{c}\text { Concentration, } \\
\%\end{array}$} & \multirow{2}{*}{$\begin{array}{l}\text { Exposure } \\
\text { per minute }\end{array}$} & \multicolumn{3}{|c|}{ Name of strain } \\
\hline & & Staphylococus & $\begin{array}{l}\text { Escherichia } \\
\text { tuphi }\end{array}$ & Penicillium \\
\hline \multirow{5}{*}{0,01} & 10 & + & + & + \\
\hline & 20 & + & + & + \\
\hline & 30 & + & + & + \\
\hline & 40 & + & $\mathbf{x}$ & - \\
\hline & 60 & + & $\mathbf{x}$ & - \\
\hline \multirow{5}{*}{0,05} & 10 & + & - & - \\
\hline & 20 & $\mathbf{x}$ & - & - \\
\hline & 30 & $\mathbf{x}$ & - & - \\
\hline & 40 & $\mathbf{x}$ & - & - \\
\hline & 60 & - & - & - \\
\hline \multirow{5}{*}{0,1} & 10 & + & $\mathbf{x}$ & - \\
\hline & 20 & $\mathbf{x}$ & - & - \\
\hline & 30 & - & - & - \\
\hline & 40 & - & - & - \\
\hline & 60 & - & - & - \\
\hline Standard: preparation in solution of $45 \%$ ethanol & + & + & + & + \\
\hline
\end{tabular}

«+»- Growth of microorganisms

«-»- Complete destruction of microorganisms

$\langle\mathbf{X} »-30-40 \%$ destruction of microorganism

\section{References:}

1. Yoshi SN, Shak KD, Chauhan NA (1991) J. Indian. Chem. Soc. 1991, 68, No. 11, pp.627 631.

2. Ichikava J, Lapointe E, Ticai Z (2007) Chem. Common. 2007, 26, pp.2693 - 2696.

3. Mustafa OS, Ahmad RA (2003) Phosphorus Sulfur Silicon Relat. Elem. 2003, 178, No. 3, pp. 475 - 480.

4. Sokolov VB, Aksenenko AY, Martynov IV (2007) Izv. RAN, Ser. Chem. 2007, 11, pp.2171 $-2177$.

5. Rozentsveig GI, Rozentsveig IB, Mirskova AV, Levtsovskaya GG (2006) Zh. Org. Khimii. 2006, 42, No. 3, pp.470 - 472.

6. Babichev FS, Sharanin YA, Litvinov VP, Promonenkov VK, Volovenko YV (1985)
Vnutrimolekulyarnoye vzaimodeystviye $\mathrm{CN}-$, $\mathrm{OH}-$ and SH-grupp; Naukova Dumka: Kiev, 1985, $199 \mathrm{P}$.

7. Zones GJ (1952) Am. Chem. Soc. 1952, 74, pp.4889 - 4892.

8. Kukhar BP, Pavlenko NG (1977) J. Org. Chem. 1977, 13, pp.92 - 96.

9. El-Gaby Mohammed SA, Tahanadia M, Micky JA, El-Sharieb MA (2002) Acta Chim. Slov.., 2002, 49, No.1, pp.159 - 164.

10. Talley JJ, Penning TD, Collins PW, et al. (2016) Patent 6586603 USA.

11. Lindyi KM, Cheng H, Sakya SM, et al. (2016) Patent 6531492 USA. 